\title{
Assessing the Relationship Between Financial Imbalances and Endogenous Regional Economic Development of Ukraine
}

\author{
Kloba Taras Lvovich, Postgraduate Student \\ Kloba Solomiia Mykhaylivna, Postgraduate Student \\ Institute of Regional Research named after \\ M.I. Dolishniy of the NAS of Ukraine, Ukraine
}

Doi:10.19044/esj.2020.v16n10p114 URL:http://dx.doi.org/10.19044/esj.2020.v16n10p114

\begin{abstract}
The article deals with the methods of evaluating the effectiveness of financial instruments in stimulating regional development. The correlation between financial imbalances and endogenously oriented regional development was evaluated using correlation-regression analysis. The main design indicators for identifying the link between financial imbalances and endogenously oriented regional development are identified: gross regional product; intergovernmental transfers; local budget revenues (tax revenues, non-tax revenues, other revenues) of Ukraine. A correlation matrix was constructed to relate the main indicators of financial imbalances and endogenous-oriented development using the correlation coefficient. The dynamics of capital investments and GRP of Ukraine and the share of capital investments in GRP of Ukraine for the years 2013-2017 are considered. The investment attractiveness of the regions of Ukraine was estimated using the index of investment attractiveness of the regions of Ukraine in 2013-2017. The matrix for revealing the connection between capital investments, gross regional product and volume of selling products (goods, services) of economic entities of endogenous-oriented development of Ukraine is constructed. It has been investigated that there are several regions that are potentially attractive to investors, namely: Volyn, Donetsk, Chernivtsi, Sumy regions, which are among the leaders and show increasing competition among themselves. It has been determined that capital investment is the most important factor in capital recovery.
\end{abstract}

Keywords: Methods of performance evaluation, correlation coefficient, correlation of financial imbalances and endogenously oriented development of regions, index of investment attractiveness, a matrix of correlation of indicators 


\section{Introduction}

As a result of the analysis of domestic and foreign practices of regional governance, it is established that the state authorities of the regions have a wide range of tools that can significantly increase financial imbalances and endogenously oriented development of the regions.

We will note the most important mechanisms of management of endogenous-oriented development of regions:

- targeting mechanism;

- social partnership mechanism;

- cluster mechanism as a means of increasing innovation activity in the region;

- a mechanism for analyzing and evaluating the sustainable development of regions.

Also, strategic planning of socioeconomic development of the regions, public-private partnership, functioning of civil society organizations occupy a priority among the mechanisms for managing the sustainable development of the region.

The linkage of these mechanisms to each other (coherence) ensures the sustainability of regional development.

Different methods can be used to evaluate the effectiveness of financial instruments in stimulating regional development (Figure 1).

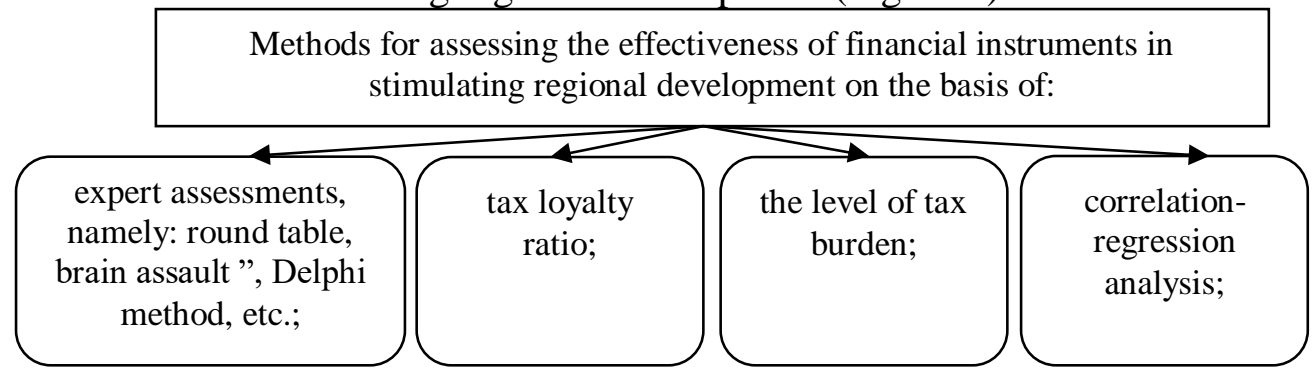

Figure 1. Methods for assessing the effectiveness of financial instruments in stimulating regional development

Source: made on the basis of (Yevstaf'yeva A. KH., 2013)

To identify the link between financial imbalances and endogenous development in the regions, we evaluated their correlation using correlation regression analysis.

More precisely, the closeness of the relationship is estimated by the correlation coefficient r. The correlation coefficient lies within $y=f\left(x_{1}, x_{2}, \ldots, x_{n}\right)$.

At $\mathrm{r}=0$ there is no connection.

If $|r|=1$, then there is a functional relationship between the two quantities. 
The correlation coefficient is determined by the formula:

$$
r_{x y}=\frac{\sum_{i=1}^{n}\left(x_{i}-\bar{x}\right)\left(y_{i}-\bar{y}\right)}{\sqrt{\sum\left(x_{i}-\bar{x}\right)^{2} \sum\left(y_{i}-\bar{y}\right)^{2}}},
$$

where $r_{x y}$ is the correlation coefficient;

$\mathrm{x}_{\mathrm{i}}, \mathrm{y}_{\mathrm{i}}$ are the current values of the observed values;

$\bar{x}, \bar{y}$, are the average values of these values.

$$
r_{x y}=\frac{\overline{x y}-\bar{x} \cdot \bar{y}}{\sigma_{x} \sigma_{y}}
$$

where ${ }^{\overline{x y}}$ is the average value of the product of two correlation values;

$\sigma_{x} \sigma_{y}$ - the mean square deviations of the corresponding values, which are defined as follows:

$$
\sigma_{x}=\sqrt{\bar{x}^{2}-(\bar{x})^{2}}
$$

For linear regression, the correlation coefficient $r$ is not only a criterion for the closeness of the bond, but also a criterion for the accuracy of approximation (the choice of the formula expressing the dependence) (Bilichenko V. V., 2017).

The estimation of accuracy approximation by curvilinear dependence is made by means of correlation relation:

$$
\eta=\sqrt{1-\frac{\sum\left(y_{i}-\tilde{y}_{i}\right)^{2}}{\sum\left(y_{i}-\bar{y}\right)^{2}}},
$$

where $y_{i}$ is the current value of the dependent variable;

$\widetilde{y}_{i}$ - theoretical values;

$\bar{y}$ - average values.

Correlative attitude takes on value $0 \leq \eta \leq 1$, it is always positive. If $\eta>r$, then, the curve approximates the dependency rather than the straight line; for straight $\eta=r$. An additional estimate of the accuracy of the approximation is often used in the estimation of nonlinear regression, is the average relative error of approximation $\bar{\varepsilon}$, which is determined by the formula: 


$$
\bar{\varepsilon}=\frac{1}{N} \sum\left|\frac{y_{i}-\bar{y}_{i}}{y_{i}}\right| 100 .
$$

When evaluating the mutual influence of three or more variables uses the multiple correlation coefficient $\mathrm{R}$, which for three variables is determined by the formula:

$$
R=\sqrt{\frac{r_{y x 1}^{2}+r_{y x 2}^{2}-2 r_{y x 1} r_{y x 2} r_{x 1 x 2}}{1-r_{x 1 \times 2}^{2}}} .
$$

When calculating the cumulative correlation coefficient, it is necessary to first determine the paired correlation coefficients $r y_{\mathrm{x} 1}, \mathrm{ry}_{\mathrm{x} 2}, \mathrm{ry}_{\mathrm{x} 3}$. Once they are all defined, they are written in a square symmetric matrix:

$$
\left[\begin{array}{cccc}
1 & r_{y x 1} & r_{y x 2} & r_{y x 3} \\
r_{y x 1} & 1 & r_{x 1 \times 2} & r_{x 1 x 3} \\
r_{y x 2} & r_{x 1 \times 2} & 1 & r_{x 2 x 3} \\
r_{y x 3} & r_{x 1 x 3} & r_{x 2 x 3} & 1
\end{array}\right] .
$$

Therefore, by the magnitude of the correlation coefficient, we can draw the following conclusion: 2017).

$0<|r|<0,2$ - virtually no communication;

$0,2<|r|<0,5$ - communication is weak;

$0,5<|r|<0,75$ - average communication;

$0,75<|r|<0,95$ - the connection is strong;

$0,95<|r|<1$ - practically functional communication (Bilichenko V. V.,

\section{Results}

The main calculation indicators for identifying the link between financial imbalances and endogenously oriented development of the regions are defined by: gross regional product; intergovernmental transfers; local budget revenues (tax revenues, non-tax revenues, other revenues) of Ukraine (Table 1). 
Table 1. Key estimates for identifying the relationship between GRP and intergovernmental transfers and local budget revenues for the years 2013-2017

\begin{tabular}{|c|c|c|c|c|c|}
\hline Indicators & 2013 & $2014^{1}$ & $2015^{1}$ & $2016^{1}$ & $2017^{1}$ \\
\hline $\begin{array}{c}\text { 1. Gross regional product, } \\
\text { UAH million }\end{array}$ & 1522657 & 1586915 & 1988544 & 2385367 & 2669010 \\
\hline $\begin{array}{c}\text { 2. Intergovernmental transfers, } \\
\text { UAH million }\end{array}$ & 115848,3 & 130600,9 & 173980,0 & 195395,3 & 250846,0 \\
\hline 3. Local budget revenues: & & & & & 201005 \\
\hline $\begin{array}{c}\text { 3.1. Tax revenues, UAH } \\
\text { million }\end{array}$ & 91191,07 & 87333,67 & 98218,36 & 146902,25 & 25969 \\
\hline $\begin{array}{c}\text { 3.2. Non-tax revenues, UAH } \\
\text { million }\end{array}$ & 12127,84 & 12257,52 & 20147,95 & 21859,20 & 2517 \\
\hline $\begin{array}{c}\text { 3.3. Other receipts, UAH } \\
\text { million }\end{array}$ & 1852,16 & 1509,89 & 2113,92 & 1986,40 & 2017 \\
\hline
\end{tabular}

1 Data are given without taking into account the temporarily occupied territory of the Autonomous Republic of Crimea, the city of Sevastopol, and part of the temporarily occupied territories in Donetsk and Luhansk regions.

Source: developed by the author of materials (Official website of the State Treasury of Ukraine; Official site of the State Statistics Service of Ukraine)

After determining the key indicators for identifying the link between financial imbalances and endogenously-oriented development of the regions for further analysis, they are tested using statistical tools for the presence of multicollinearity, namely a close correlation between the factors selected for the analysis, which jointly affect the resultant indicator (Orlova I.V., Filonova E.S., 2015).

The correlation matrix of the relationship between the main indicators of financial imbalances and endogenously oriented development is given in Table. 2.

Table 2. Correlation matrix of the relationship between GRP and intergovernmental transfers and local budget revenues of endogenously oriented development of Ukraine

\begin{tabular}{|c|c|c|c|c|c|}
\hline $\begin{array}{c}\text { Correlation } \\
\text { coefficient (r) }\end{array}$ & $\begin{array}{c}\text { Gross } \\
\text { regional } \\
\text { product }\end{array}$ & $\begin{array}{c}\text { Intergovern } \\
\text { mental } \\
\text { transfers }\end{array}$ & $\begin{array}{c}\text { Tax } \\
\text { revenues }\end{array}$ & $\begin{array}{c}\text { Non-tax } \\
\text { revenues }\end{array}$ & $\begin{array}{c}\text { Other } \\
\text { receipts }\end{array}$ \\
\hline $\begin{array}{c}\text { Gross } \\
\text { regional product }\end{array}$ & 1 & 0,982822 & 0,939695 & 0,978364 & 0,836469 \\
\hline $\begin{array}{c}\text { Intergovernmental } \\
\text { transfers }\end{array}$ & 0,982822 & 1 & 0,941243 & 0,976820 & 0,872536 \\
\hline Tax revenues & 0,939695 & 0,941243 & 1 & 0,877902 & 0,825974 \\
\hline Non-tax revenues & 0,978364 & 0,976820 & 0,877902 & 1 & 0,889309 \\
\hline Other receipts & 0,836469 & 0,872536 & 0,825974 & 0,889309 & 1 \\
\hline
\end{tabular}

Source: Data calculated by the author

According to the Table 2 it is possible to determine the existence of a correlation between the main indicators of financial imbalances for determining the factors of stimulation of endogenously oriented development 
of Ukraine and the regions in particular.

According to the calculations, a strong correlation between all the factors can be stated, as evidenced by the high indices of the paired regression coefficient $(0,75<|r|<0,95$ ), and can also be used to assess the conflict of key indicators for the gross regional product.

According to the calculated data Table 2, we observe that today there is a close relationship between gross regional product volumes, intergovernmental transfers, tax and non-tax revenues to local budgets. At the same time, the introduction of effective financial instruments to stimulate tax revenues to local budgets will directly affect the gross regional product in the regions.

The estimation with the help of the correlation matrix confirms sufficient dependence of gross regional product on intergovernmental transfers and revenues of local budgets of Ukraine.

One of the financial instruments for stimulating the financial imbalances of endogenously oriented regional development is targeted financially. State support for territories in Ukraine provides for the allocation of earmarks budget funds for the implementation of programs for their development. According to the current legislation of Ukraine, the functional allocation of budgetary funds may be carried out in the following directions, namely:

- financing of regional development agreements;

- financing of territorial depression programs;

- state capital investments in the development of industrial, communication and social infrastructure of the territories;

- financial support for small businesses;

- Formation of objects of enterprise development infrastructure;

- Financing of programs of retraining and professional development of labor resources (Vusyatytska M. P., 2014).

Among the proportions that are important from the point of view of the economic development of Ukraine and the regions in particular, we should highlight the share of capital investments in Ukraine's GRP.

The dynamics of capital investments and GRP of Ukraine and the share of capital investments in GRP of Ukraine for 2013-2017 are shown in Figure 2.

According to Figure 2 we observe that the share of capital investments in the gross regional product has a growing trend, except for the period 20142015, when the effects of the 2014 financial crisis were affected by the decline in financing volumes. 


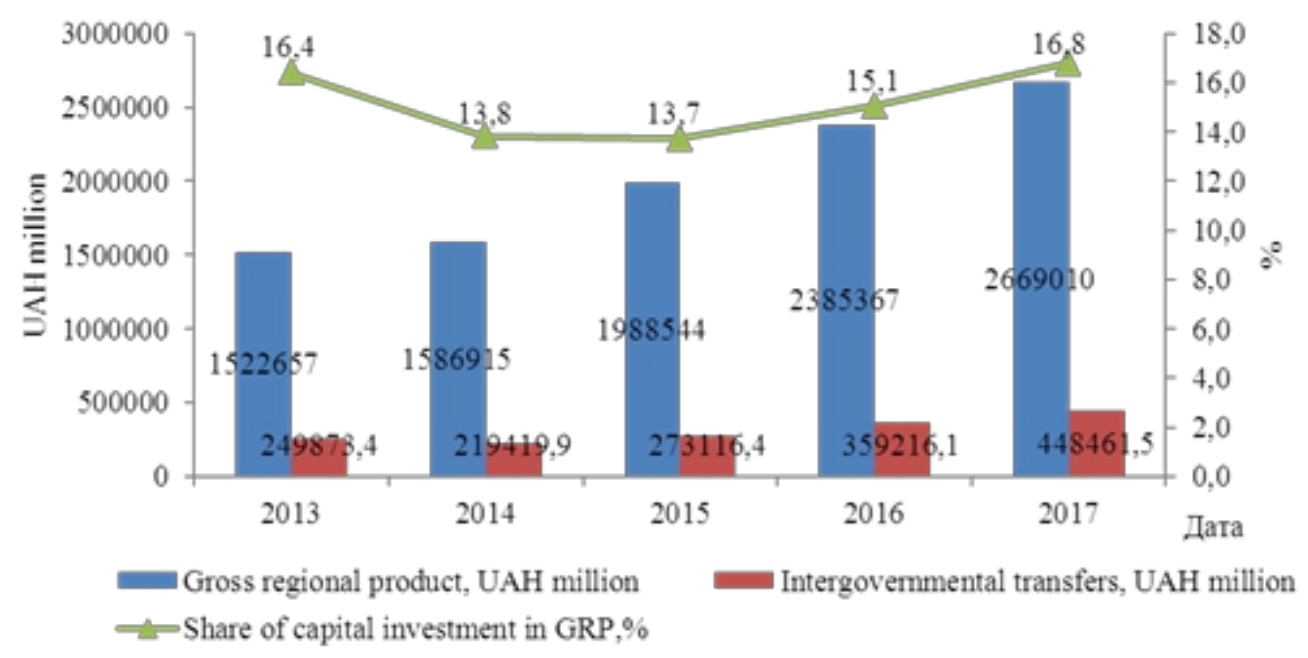

Figure 2. Dynamics of capital investments and GRP of Ukraine and share of capital investments in GRP of Ukraine for 2013-2017

Source: developed by the author of materials (Official website of the State Treasury of Ukraine; Official site of the State Statistics Service of Ukraine)

In spite of the positive dynamics, there are problems that are holding back investment in the region:

- insufficient funds of the regional budget aimed at supporting investment activities;

- delay in the preparation of infrastructure on the land plots proposed for the creation of industrial parks;

- lag in the development of infrastructure of sites on which investors implement projects for the construction of new enterprises, objects of engineering and transport infrastructure;

- a small number of new innovative projects aimed at modernization of the economy and its diversification, and as a consequence, low level of investments in innovations, which would allow the continuous updating of technical and technological base of production, reduce costs, develop and produce new competitive products to penetrate into the world markets of goods and services;

- uneven development, including investment, of municipalities of the region;

- the complexity and duration of the established procedures for obtaining permits and approvals for the start of the investment project.

Nowadays, it is necessary to attract financial resources, that is, to assess the investment attractiveness of the regions of Ukraine, which will allow the future investor to assess the investment climate and alternatives and the expected returns they might bring for them. 
The investment attractiveness of regions of Ukraine is estimated using the investment attractiveness index. The dynamics of the index of investment attractiveness of the regions of Ukraine for 2013-2017 is shown in Figure 3.

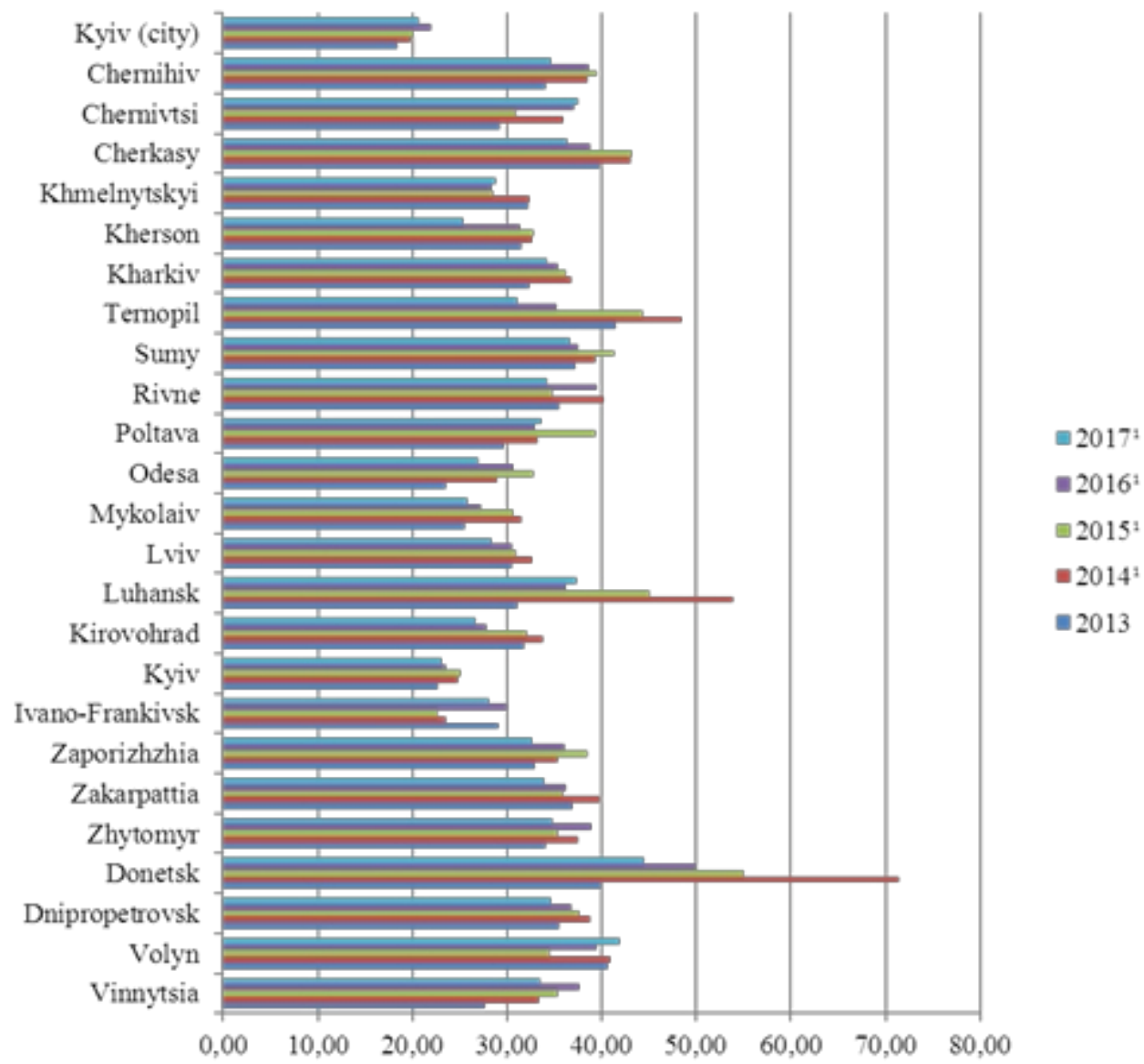

Figure 3. Index of investment attractiveness of regions of Ukraine for 2013-2017 Source: developed by the author of materials (Official website of the State Treasury of Ukraine; Official site of the State Statistics Service of Ukraine)

Studies have shown that the following regions are potentially attractive to investors in 2017: Sumy (36.59), Chernivtsi (37.44), Volyn (41.96), Donetsk (44.44) leaders and show increasing competition among themselves. At the same time, the disparity in the investment attractiveness of the regions is caused by the uneven development of the endogenous oriented development of the regions of Ukraine.

The main calculation indicators for identifying the link between financial imbalances and endogenously oriented development of the regions are defined by: gross regional product; intergovernmental transfers; local budget revenues (tax revenues, non-tax revenues, other revenues) of Ukraine 
(Table 3).

Table 3. The main calculated indicators for identifying the relationship between capital investment, gross regional product and volume of sales of products (goods, services)

of entities of endogenous-oriented development of Ukraine in 2013-2017

\begin{tabular}{|c|c|c|c|c|c|}
\hline Indicators & 2013 & $2014^{1}$ & $2015^{1}$ & $2016^{1}$ & $2017^{1}$ \\
\hline $\begin{array}{c}\text { 1. Gross regional product, } \\
\text { UAH million. }\end{array}$ & 1522657 & 1586915 & 1988544 & 2385367 & 2669010 \\
\hline $\begin{array}{c}\text { 2. Capital investment, } \\
\text { UAH million }\end{array}$ & 249873,4 & 219419,9 & 273116,4 & 359216,1 & 448461,5 \\
\hline $\begin{array}{c}\text { 3. Volume of sales of } \\
\text { products (goods, services) } \\
\text { of economic entities, UAH } \\
\text { million }\end{array}$ & 4334453,1 & 4459702,2 & 5716431,0 & 6877077,3 & 8467031,9 \\
\hline
\end{tabular}

1 Data are given without taking into account the temporarily occupied territory of the Autonomous Republic of Crimea, the city of Sevastopol, and part of the temporarily occupied territories in Donetsk and Luhansk regions.

Source: developed by the author of materials (Official website of the State Treasury of Ukraine; Official site of the State Statistics Service of Ukraine)

The correlation matrix for identifying the relationship between capital investment, gross regional product and volume of sales of products (goods, services) of economic entities of endogenously oriented development of Ukraine is given in Table 4.

Table 4. Correlation matrix for identifying the relationship between capital investment, gross regional product and volume of sales of products (goods, services) of entities of endogenous-oriented development of Ukraine

\begin{tabular}{|c|c|c|c|}
\hline Correlation coefficient (r) & $\begin{array}{c}\text { Capital } \\
\text { investment }\end{array}$ & $\begin{array}{c}\text { Gross } \\
\text { regional } \\
\text { product }\end{array}$ & $\begin{array}{c}\text { Volume of sales of } \\
\text { products (goods, } \\
\text { services) of economic } \\
\text { entities }\end{array}$ \\
\hline Capital investment & 1 & 0,960051 & 0,979629 \\
\hline Gross regional product & 0,960051 & 1 & 0,99115 \\
\hline $\begin{array}{c}\text { Volume of sales of products } \\
\text { goods, services) of economic } \\
\text { entities }\end{array}$ & 0,979629 & 0,991150 & 1 \\
\hline
\end{tabular}

Source: Data calculated by the author

The analysis of correlation (Table 3) between factors and volume of investments, conducted using the matrix of paired correlations, made it possible to conclude that the close correlation with capital investments (coefficient of correlation $(0,75<|r|<0,95$ ) have GRP and output (goods, services) of economic entities.

Therefore, capital investment is a major factor in capital renewal, increased production efficiency and, as a consequence, increased GRP 
volumes. In this regard, the most representative study of the impact of capital investment on the GRP label appears to be the most representative.

\section{Conclusion}

From the results obtained, it is worth noting that in Ukraine and the regions in particular, there is a close link between financial imbalances and endogenously oriented development of the regions, which we examined using a correlation matrix of relevant indicators.

The proposed complex of identifying the link between financial imbalances and endogenously oriented development of the regions of Ukraine with the help of correlation matrices can be considered as a tool to support decision-making in the scenario analysis of strategic alternatives to the development of regions, to evaluate their effectiveness and to substantiate strategic norms in particular areas.

\section{References:}

1. Yevstaf'yeva A. KH. (2013). Methods of assessing the effectiveness of tax policy in the region. Vestnik of Perm University. 3(18), 23-31.

2. Bilichenko V. V. (2017). Modeling of technological processes of road transport enterprises. Retrieved from https://web.posibnyky.vntu.edu.ua/fmbt/avto6_bilichenko_modelyuvt ehproces_avtotransportu/p3.html

3. Official website of the State Treasury of Ukraine. Retrieved from http://treasury.gov.ua

4. Official site of the State Statistics Service of Ukraine. Retrieved from http://www.ukrstat.gov.ua

5. Orlova I.V., Filonova E.S. (2015). The choice of exogenous factors in the regression model with multicollinearity of data. International Journal of Applied and Fundamental Research, no. 5, pp. 108-116.

6. Vusyatytska M. P. (2014). Analysis of the financial levers of the state in promoting regional economic development. Retrieved from http://www.economy.nayka.com.ua/?op=1\&z=3506 